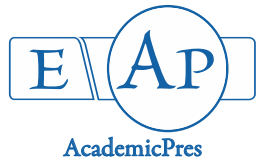

\title{
The Effects of Nitrogen Source on Nutritive Value of Irrigated Silage Corn
}

\author{
Seyfollah FALLAH*, Solmaz NEISANI
}

\author{
Shahrekord University, Faculty of Agriculture, Department of Agronomy, PO Box 115, Shahrekord, \\ Iran;falab1357@yahoo.com (*orrespondingauthor)
}

\begin{abstract}
Nitrogen is considered one of the most important nutrients affecting yield and quality of maize forage (Zea mays L.). A two-year field experiment was carried out to evaluate the effects of broiler litter and mineral fertilizer on dry matter production and silage quality of corn. The applied treatments were: unfertilized (control), 100, 200 and $300 \mathrm{~kg} \mathrm{ha}^{-1}$ in the form of urea

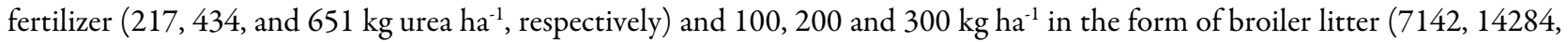
and $21426 \mathrm{~kg}$ broiler litter ha ${ }^{-1}$, respectively). The present findings showed that $\mathrm{Fe}, \mathrm{Mn}, \mathrm{Cu}$ and $\mathrm{Zn}$ concentrations in forage corn were not affected by urea application; however, broiler litter application significantly increased $\mathrm{Fe}, \mathrm{Mn}$ and $\mathrm{Cu}$ concentrations of corn stover in a linear trend. The broiler litter and urea fertilizer significantly increased both dry matter and protein content of forage corn but no significant differences on those components were obtained between broiler litter and urea fertilizer at each $\mathrm{N}$ application rate. The results suggested that $\mathrm{N}$ applied to forage corn by broiler litter, at the recommended rate for inorganic $\mathrm{N}$ fertilization, is almost more effective in terms of forage nutritive value response than urea fertilizer. The profitability of forage corn production could be enhanced by replacing chemical fertilizers with broiler litter.
\end{abstract}

Keywords: Zea mays L., acid detergent fiber, broiler litter, micronutrient, protein

\section{Introduction}

Forage corn (Zea mays L.) is an excellent feed for dairy cattle due to its high dry matter yield, energy content, and palatability, especially when mixed with other feeds (Hart et al., 2009). Nitrogen is the most important fertilizer for forage corn production (Hart et al., 2009) and the application of this nutrient affects the forage yield of corn while improving its quality, especially its protein content (Amanullah et al., 2009). Moreover, low and high doses of nitrogen have an adverse effect on quality of corn (Stone et al., 1998) and an efficient management of nitrogen fertilizer is critical for the long-term protection of environmental quality (Fallah and Tadayyon, 2010). Thus, it is necessary to determine the optimum dose of $\mathrm{N}$ to improve the quality of corn (Li et al., 2010).

Manure produced by poultry industry is capable of causing serious environmental pollution, but agronomic management practices on the use of manure could transform it from a waste to a resource product (Annicchiarico et al., 2011). The expansion of the broiler industry and an increase in the price of anorganic fertilize, especially $\mathrm{N}$, has increased the use of broiler litter as a source of crop nutrients. The poultry manure is recognized as a valuable natural fertilizer because of its high $\mathrm{N}$ content (Ma et al., 1999). Among the types of organic manure, poultry manure is used as a soil amendment for agricultural crops and provides appreciable quantities of all important plant nutrients (Schomberg et al., 2009).

$\mathrm{Cu}, \mathrm{Zn}, \mathrm{Fe}$ and $\mathrm{Mn}$ in forage affect directly food quality and are closely related to livestock nutrition. In addition, the concentrations of crude protein, neutral detergent fiber (NDF), and acid detergent fiber (ADF), and the digestibility of these nutrient components influence the energy value of feedstuff(Weiss, 1994).

Although most of the nitrogen and phosphorus required by corn is provided through chemical fertilizers (Fallah et al., 2013), broiler litter might increase corn performance with a residual effect on succeeding crops (Fallah et al., 2013). Besides, of its application for increasing of arable land productivity, broiler litter might minimize the risk of the broiler litter accumulation near the poultry farms.

Land application of manures for crop production has increased in recent years due to the concerns related to crop quality and due to the commercial fertilizer cost. Furthermore, forage producers often have insufficient information for application of broiler litter at agronomically and environmentally acceptable rates. In addition comparative information is needed on nutrients efficiency from commercial nitrogen fertilizer, and broiler litter. Studies of broiler litter as a source of nitrogen can help elucidate the value of this manure as 
an alternative source of nutrients for corn production given the economic challenges of the rising cost of commercial fertilizer. The objective of the present study was to evaluate the effect of adding broiler litter and urea fertilizer on dry matter and protein yield, micronutrient concentration, and digestibility of corn. Results provided information for applying broiler litter safely and effectively to silage corn production.

\section{Materials and Methods}

\section{Study site description}

A field experiment was conducted at the Agricultural Research Farm of Shahrekord University in Iran $\left(32^{\circ} 21^{\prime} \mathrm{N}\right.$ latitude, 50'49' E longitude; elevation $=2050 \mathrm{~m}$ ). The Emberger and Gossen classification for this area described it as arid with a cold steppe climate. The mean annual rainfall is 334 $\mathrm{mm}$ and annual temperature is $10.8^{\circ} \mathrm{C}$. The annual rainfall does not coincide with the corn-growing season and the air temperature is relatively high. The total rainfall during the corn-growing season (June to September) is $5.9 \mathrm{~mm}$.

The site soil was calcareous with more than $30 \%$ equivalent calcium carbonate in the surface layer that has developed into limestone. The used soil had never been fertilized with organic manure. Soil samples taken from $0-30 \mathrm{~cm}$ in depth were analysed for its characteristics before the experiment (Table 1). Soil texture, $\mathrm{pH}$ ( $\mathrm{pH}_{\mathrm{H} 2 \mathrm{O}}$ at 1:2.5 ratio), electrical conductivity, organic carbon (Walkley-Black method), total nitrogen (Kejldahl method), extractable P (Olsen method), available K, and $\mathrm{CaCO}_{3}$ content were determined as described by Carter and Gregorich (2008). DTPA-extractable Cu, Zn, Fe and Mn levels were obtained by combining $10 \mathrm{~g}$ of soil $(\leq 2 \mathrm{~mm})$ with $20 \mathrm{ml} 0.005 \mathrm{M}$ DTPA + $0.01 \mathrm{M} \mathrm{CaCl} 2+0.1$ MTEA (triethanolamine) solution. After $2 \mathrm{~h}$ of continuous shaking at room temperature, the soil suspension was centrifuged and filtered through a $0.45 \mu \mathrm{m}$ membrane. $\mathrm{Cu}, \mathrm{Zn}, \mathrm{Fe}$, and $\mathrm{Mn}$ levels in the suspension were determined using an atomic absorption spectrometer (Page et al., 1982).

Broiler litter was obtained from a Poultry Farm at Shahrekord University nearby the experimental site. The litter was made up of the feces mixed with different proportions of sawdust bedding. All litter samples were air-dried and ground to $1 \mathrm{~mm}$ for analysis. The manure, EC, OC, total N, P, and $\mathrm{K}$ were measured and analysed for their chemical properties (Table 1).

\section{Experimentalsetup}

The experimental setup was a randomized complete block design with four replications. Each replication was divided into seven $\mathrm{N}$ treatments (control, 100, 200, and $300 \mathrm{~kg} \mathrm{~N} \mathrm{ha}^{-1}$ each of urea fertilizer and broiler litter). Plant-available $\mathrm{N}$ was calculated based on the assumption that $50 \%$ of organic $\mathrm{N}$ in broiler litter mineralizes in the first year of application (Fallah et al., 2013).

The field was ploughed once using a moldboard plow and twice using a disc harrow; ridges were formed every $60 \mathrm{~cm}$. Each experimental plot was designed as $4.2 \mathrm{~m}$ wide and $9 \mathrm{~m}$ long. After seedbed preparation, the desired broiler litter rates were immediately banded $9 \mathrm{~cm}$ below the seed and were covered with soil. In inorganic treatments, one-third of the $\mathrm{N}$ fertilizer as urea and all of the super triple superphosphate fertilizer were added to the soil manually on the sides of the ridges before planting the corn. The remaining $\mathrm{N}$ was added at the 7-9 leaf stage. Potassium fertilizer was not applied to the soil because the initial level of $\mathrm{K}$ in the soil was $344 \mathrm{mg} \mathrm{kg}^{-1}$ (Table 1).

Corn seeds (SC 704) were planted in the month of May in 2008 and 2009 at a rate of 140000 plant ha $^{-1}$. Immediately after sowing, all the plots were irrigated every 4-7 day based on environmental conditions to improve the rate of emergence. There were no major pests or diseases that required chemical control.

\section{Analysis of corm plants}

At the harvesting stage (progression of milk line in corn kernels), the corn shoots of five plants from the central rows were sampled randomly from each plot. Plant leaf, plant stem, and ear samples to be dried were placed in an oven at $60^{\circ} \mathrm{C}$ until a constant weight was reached and the dry weights were calculated (Kacar, 1972).

The nitrogen content of the dried samples was determined using the Kjeldahl method and the Gerhardf Vapodest model (Jackson, 1962). Crude protein was calculated by multiplying the total $\mathrm{N}$ by 6.25 (Bremner and Breintenbeck, 1983). The $\mathrm{Fe}, \mathrm{Mn}, \mathrm{Zn}$ and $\mathrm{Cu}$ concentrations were determined by flame atomic absorption spectrophotometer (FAAS) with suitable matrices after samples were digested by nitric acid and hydrogen peroxide. All results were recalculated on a $105^{\circ} \mathrm{C}$ oven-dry basis (Carter and Gregorich, 2008).

Table 1. Main variables of soil and broiler litter for the experiment

\begin{tabular}{|c|c|c|c|c|c|}
\hline \multirow{2}{*}{ Parameter } & \multirow{2}{*}{ Unit } & \multicolumn{2}{|c|}{ Soil } & \multicolumn{2}{|c|}{ Broiler litter } \\
\hline & & 2008 & 2009 & 2008 & 2009 \\
\hline Texture & - & Clay loam & Clay loam & - & - \\
\hline $\mathrm{pH}$ & - & 8.34 & 7.84 & 8.21 & 6.41 \\
\hline EC & $\left(\mathrm{dS} \mathrm{m}^{-1}\right)$ & 0.25 & 0.86 & 1.1 & 12.7 \\
\hline OC & $\left(\mathrm{g} \mathrm{kg}^{-1}\right)$ & 3.6 & 3.7 & 368 & 400 \\
\hline $\mathrm{N}$ & $\left(\mathrm{g} \mathrm{kg}^{-1}\right)$ & 0.22 & 0.03 & 26 & 30 \\
\hline $\mathrm{P}$ & $\left(\mathrm{mg} \mathrm{kg}^{-1}\right)$ & 18 & 11.5 & 7423 & 10560 \\
\hline K & $\left(\mathrm{mg} \mathrm{kg}^{-1}\right)$ & 350 & 344 & 9927 & 11454 \\
\hline $\mathrm{C} / \mathrm{N}$ & - & 16.4 & 12 & 14.15 & 13.33 \\
\hline $\mathrm{Fe}$ & $\left(\mathrm{mg} \mathrm{kg}^{-1}\right)$ & 6.5 & 4.98 & 527 & 878 \\
\hline $\mathrm{Mn}$ & $\left(\mathrm{mg} \mathrm{kg}^{-1}\right)$ & 4.3 & 5.21 & 88 & 142 \\
\hline $\mathrm{Zn}$ & $\left(\mathrm{mg} \mathrm{kg}^{-1}\right)$ & 0.90 & 0.81 & 448 & 453 \\
\hline $\mathrm{Cu}$ & $\left(\mathrm{mg} \mathrm{kg}^{-1}\right)$ & 0.55 & 0.56 & 28 & 26 \\
\hline
\end{tabular}


118

NDF samples $(0.3 \mathrm{~g})$ were analysed by wet chemistry for whole-plant NDF and ADF as recommended by Van Soest $e t$ al. (1991). Levels of NDF and ADF for calibration sets were determined using the ANKOM filter bag system (ANKOM Technologies, 2003) to include a $120 \mathrm{~min}$ reflux and $4 \mathrm{~min}$ rinse with a $1.0 \mathrm{~g} \mathrm{~kg}^{-1}$ heat stable $\alpha$-amylase solution (Mertens, 1991). All compositional data were calculated on a DM basis. Protein yield was determined as a function of biomass yield and biomass protein concentration (Martin et al., 1998).

\section{Statistical analyses}

All the analyses were performed based as a randomized complete block design. Data from both years were combined. Each data point was the mean of two years and four replicates $(\mathrm{n}=8)$ and the least significant difference (LSD) option of Statistical Analysis System software (Version 9.1.3; SAS Institute; USA). The data were analysed using one-way and regression analysis ANOVA and mean comparison was performed by Fisher's least significant difference (LSD) test ( $p$ $\leq 0.05)$.

\section{Results and Discussion}

\section{Micronutrients}

There were no significant differences in nutrients concentration, except for Fe and Mn concentrations, between 2008 and 2009 (Table 2). The mean of $\mathrm{Fe}$ and $\mathrm{Mn}$ concentrations for forage corn were $73 \%$ and $23 \%$ greater, respectively, in 2009 than in 2008 (Fig. 1). In 2008, there were no significant differences between same nitrogen rates in the form of urea fertilizer and broiler litter, however in 2009 nitrogen levels in the form of broiler litter increased than the nitrogen levels in the form of urea fertilizer (Fig. 1). This might be the results of increased Fe and Mn concentrations in the broiler litter in 2009 (Table 2). It appears that the use of broiler litter with an appropriate concentration of micronutrients is the best strategy for strengthening these nutrients in crops (Adeli $e t$ al., 2015). Increased plant growth associated with increased $\mathrm{N}$ supply may explain, in part, the increased uptake observed for other nutrients (Nyiraneza and Snapp, 2007).

\section{Iron}

The ANOVA analysis shows that Fe concentration was significantly affected by nitrogen amendment (Table 2). Fe concentrations for forage corn were $18 \%$ after $\mathrm{N}$ amendment than in the unfertilized plots. Also, there were significant increases in Fe concentration for forage corn caused by broiler litter application over chemical fertilizer rates (Fig. 2). The increased $\mathrm{Fe}$ concentration was the result of the high rate of these minerals in the litter, particularly in the second-year litter application (Table 2). Similar results has reported that applied poultry manure increased concentration of $\mathrm{Zn}$ in tomato and wheat plants (Yaduvanshi and sharma; Demir, et al., 2010), but had no significant effects on the concentrations Fe in tomato plants (Demir, et al., 2010).

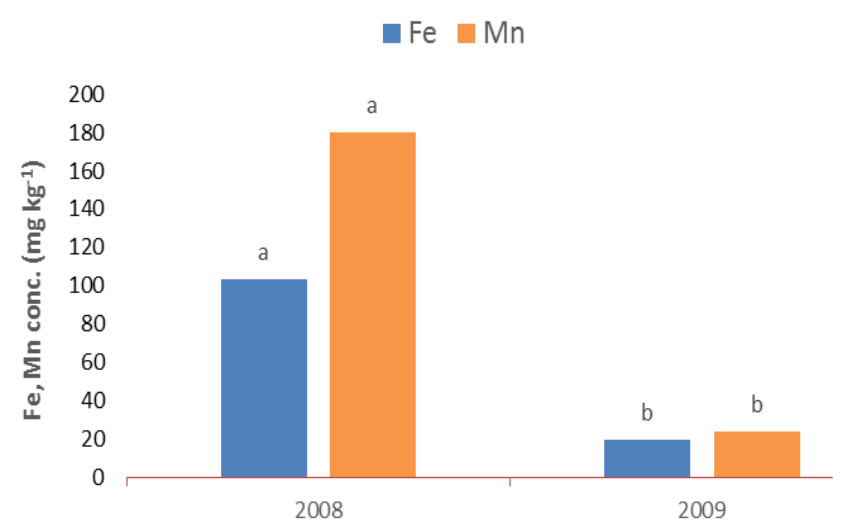

Fig. 1. Fe and Mn concentration of silage corn in 2008 and 2009. Means with the different letters show significant difference (LSD, $\mathrm{P} \leq 0.05$ )

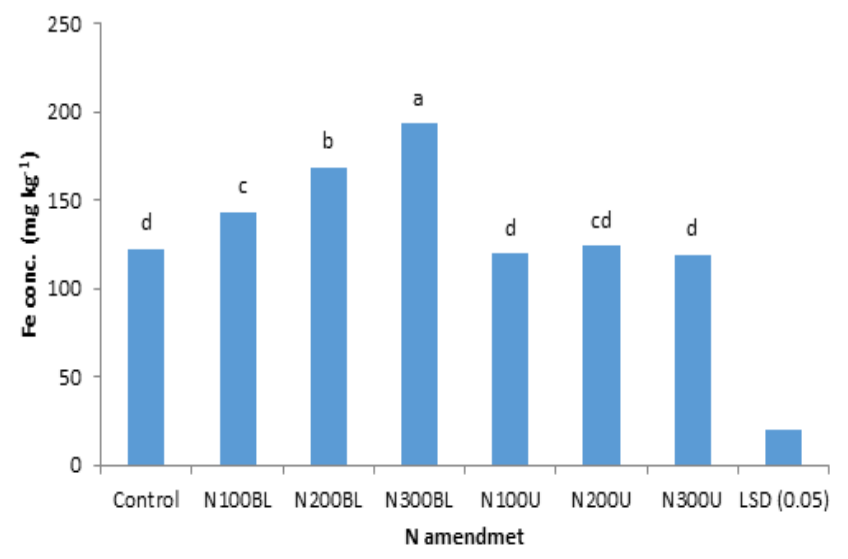

Fig. 2. The effects of $\mathrm{N}$ source and rate on Fe concentration of silage corn. Control: without chemical fertilizer and broiler litter; $\mathrm{N}_{100 \mathrm{U}}, \mathrm{N}_{200 \mathrm{U}}$, and $\mathrm{N}_{300 \mathrm{U}}: 100,200$ and $300 \mathrm{~kg} \mathrm{ha}^{-1}$ of $\mathrm{N}$ as urea fertilizer, respectively; $\mathrm{N}_{100 \mathrm{BL}}, \mathrm{N}_{200 \mathrm{BL}}$, and $\mathrm{N}_{300 \mathrm{BL}}$ : 100, 200 and $300 \mathrm{~kg} \mathrm{ha}^{-1}$ of $\mathrm{N}$ as broiler litter, respectively. Means with the different letters show significant difference (LSD, P $\leq$ $0.05)$

Table 2. The effects of $\mathrm{N}$ source and rate on micro nutrients concentration, and NDF of silage corn

\begin{tabular}{|c|c|c|c|c|c|}
\hline S.O.V & $\mathrm{Fe}$ & $\mathrm{Mn}$ & $\mathrm{Zn}$ & $\mathrm{Cu}$ & $\mathrm{NDF}+$ \\
\hline Year & $* *$ & ** & NS‡ & NS & NS \\
\hline $\mathrm{N}$ amendment & ${ }^{* *}$ & $* *$ & ** & ** & ** \\
\hline Year $\times \mathrm{N}$ amendment & ${ }^{* *}$ & NS & NS & NS & NS \\
\hline Litter linear & ${ }^{* *}$ & $* *$ & $* *$ & ** & $*$ \\
\hline Litter quadratic & NS & NS & NS & NS & NS \\
\hline Fertilizer linear & NS & NS & NS & NS & NS \\
\hline Fertilizer quadratic & NS & NS & NS & NS & NS \\
\hline
\end{tabular}

${ }^{*}$ Significant at $\mathrm{P} \leq 0.05 .{ }^{* *}$ Significant at $\mathrm{P} \leq 0.01$

† NDF, Nutrient detergent fiber. $\neq N S$, not significant 


\section{Manganese}

Effect of nitrogen on Mn concentration in forage corn varied between nitrogen source in 2008 and 2009 and showed an inconsistent trend (Table 2). In broiler treated plots, $\mathrm{Mn}$ concentrations were significantly higher than the urea treated plots (Fig. 3) and showed a linear trend (Table 2). With chemical fertilizer in both years, however, no trend due to nitrogen rate was visible and $\mathrm{Mn}$ concentration in high nitrogen level (300 $\mathrm{kg} \mathrm{ha}^{-1}$ ) stayed always below the corresponding results with broiler litter (Table 2). Khaliq and Abbasi (2010) showed that combination of organic-inorganic amendments increased soil organic matter content by $3-9 \%$, total N 14-29\%, available P 5-35\% and extractable K 12$39 \%$. The response of micronutrient to organic or organicinorganic amendments was even higher than that recorded for macronutrients.

\section{Zinc}

The effect of nitrogen on $\mathrm{Zn}$ concentration in forage corn varied between nitrogen sources (Table 2). Zn concentration was bigger in both years in broiler litter compared to urea fertilizer treatments (Fig. 4). Zn concentration was lowest in unfertilized plot and urea fertilizer plots. In broiler treated plots, $\mathrm{Zn}$ concentration was significantly higher the urea treated plots (Fig. 4) and showed a linear trend (Table 2). Phosphorus has a vital role in energy storage and root development. According to Mohanty et al. (2006), poultry manure had induced more $\mathrm{p}$ uptake from soil, and increased root growth associated with increased $\mathrm{P}$ supply may explain, in part, the increased uptake observed for other nutrients. Additionally, Shakhawat et al. (2016) attributed that chemical
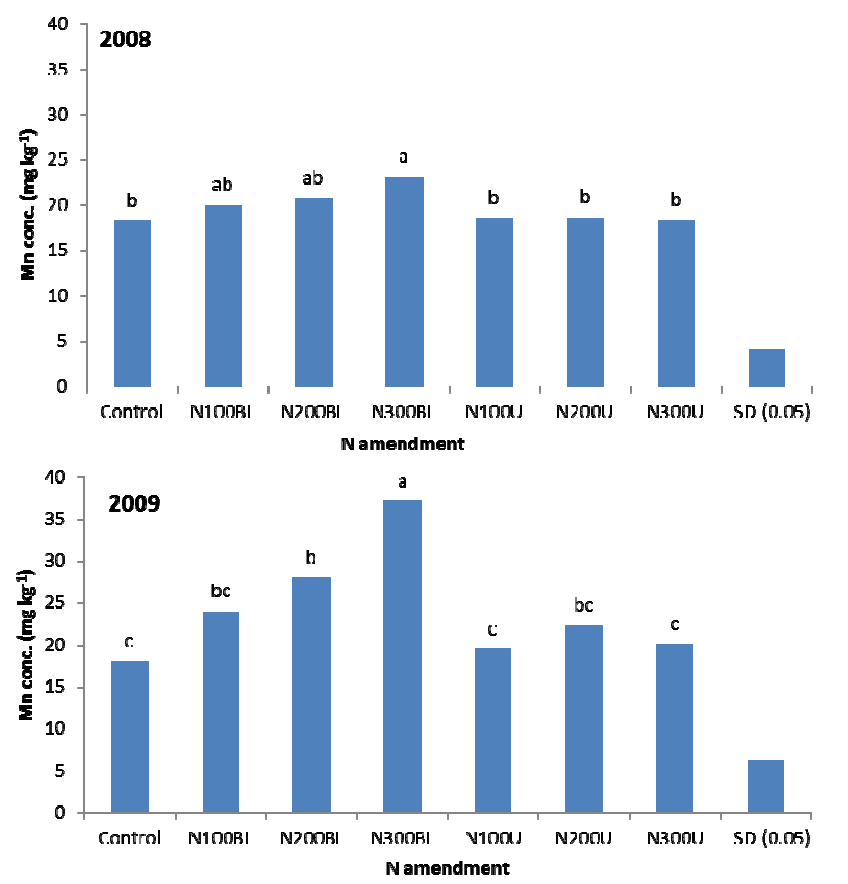

Fig. 3. The effects of $\mathrm{N}$ source and rate on $\mathrm{Mn}$ concentration of silage corn in 2008 and 2009. Control: without chemical fertilizer and broiler litter; $\mathrm{N}_{100 \mathrm{U}}, \mathrm{N}_{200 \mathrm{U}}$, and $\mathrm{N}_{300 \mathrm{U}}: 100,200$ and $300 \mathrm{~kg} \mathrm{ha}^{-1}$ of $\mathrm{N}$ as urea fertilizer, respectively; $\mathrm{N}_{1 \text { оов }}$, $\mathrm{N}_{200 \mathrm{BL}}$, and $\mathrm{N}_{300 \mathrm{BL}}: 100,200$ and $300 \mathrm{~kg} \mathrm{ha}^{-1}$ of $\mathrm{N}$ as broiler litter, respectively. Means with the different letters show significant difference $(\mathrm{LSD}, \mathrm{P} \leq 0.05)$ fertilizers alone could not provide adequate and balanced nutrition for potential crop yield. But, total $\mathrm{N}$, available $\mathrm{P}$ and available $\mathrm{Zn}$ improved in treatments that included poultry manure.

\section{Copper}

Copper (Fig. 5) in the forage corn increased with increasing rate of nitrogen from broiler litter but decreased with increasing rate of nitrogen from urea fertilizer. In both years, plots fertilized with urea fertilizer showed the same effect for $\mathrm{Cu}$ concentration of forage corn and there were no clear trend among nitrogen levels (Fig. 5). Cu concentration in forage corn was higher at $300 \mathrm{~kg} \mathrm{~N}^{-1}$ ha form broiler litter than urea fertilizer (Fig. 5).

The use of organic manure increased the $\mathrm{Fe}, \mathrm{Mn}$, and $\mathrm{Cu}$ concentrations as the application rate increased, but the $\mathrm{Zn}$ concentration remained unchanged. Mineral supplementation of livestock feeds often enriches their manure and the soil to which they are applied with $\mathrm{Cu}$ and $\mathrm{Zn}$ (Mikkelsen, 2000). In urea fertilized plots, nutrient removal values for $\mathrm{Cu}$ and $\mathrm{Zn}$ are relatively low compared with the amounts of these nutrients that could be present in a typical manure application. In semiarid conditions, low organic matter and high $\mathrm{pH}$ of soil decreased micronutrients uptake by plant (Fallah et al., 2013).

To use broiler litter as an illustration, a single application at a rate of $11.2 \mathrm{Mg} \mathrm{ha}^{-1}$ could potentially add the following nutrient amounts: $\mathrm{Fe}=7.3 ; \mathrm{Mn}=3.8 ; \mathrm{Zn}=3.5$; and $\mathrm{Cu}=2.5$ $\mathrm{kg} \mathrm{ha}^{-1}$ (Heckman et al., 2003). The application of appropriate rates of nitrogen fertilizer can increase soil $\mathrm{Cu}, \mathrm{Zn}$, and $\mathrm{Mn}$ availability and the concentrations of $\mathrm{Cu}, \mathrm{Zn}, \mathrm{Fe}$, and $\mathrm{Mn}$ in corn. Similar results regarding increased micronutrient uptake

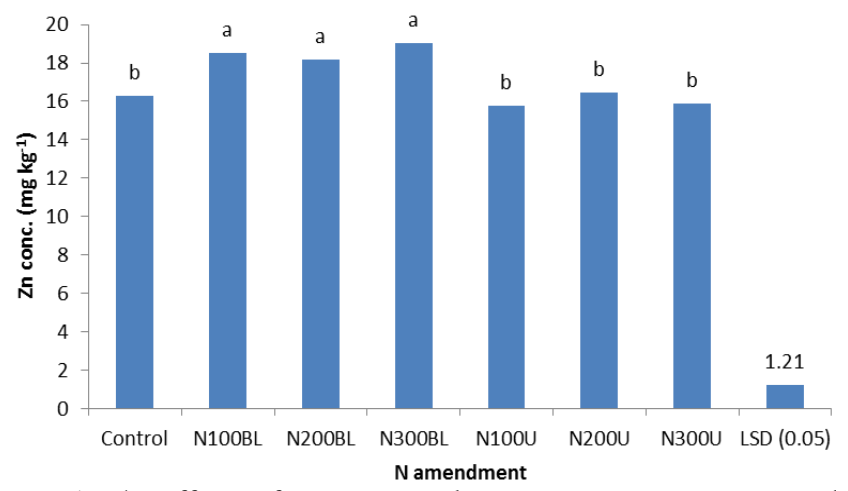

Fig. 4. The effects of $\mathrm{N}$ source and rate on $\mathrm{Zn}$ concentration of silage corn. Means with the different letters show significant difference (LSD, $\mathrm{P} \leq 0.05$ ). See Fig. 2 for abbreviations

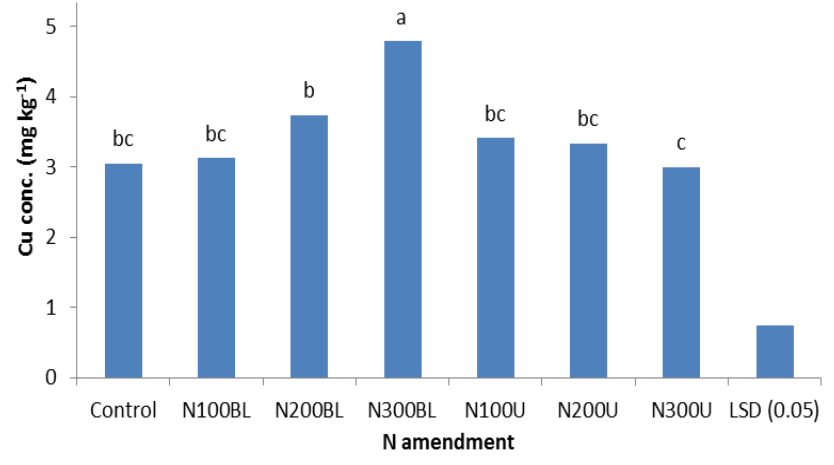

Fig. 5. The effects of $\mathrm{N}$ source and rate on $\mathrm{Cu}$ concentration of silage corn. Means with the different letters show significant difference (LSD, P $\leq 0.05$ ). See Fig. 2 for abbreviations 
120

with manure application have been reported for wheat by Zhang et al. (2015). Several authors have reported $\mathrm{Cu}, \mathrm{Zn}, \mathrm{Fe}$, $\mathrm{Mn}, \mathrm{Mg}$, and $\mathrm{Ca}$ concentrations in rice and cotton initially increased and then decreased as the $\mathrm{N}$ dose applied continued to increase ( Hao et al., 2007; Adeli et al., 2015).

\section{Neutral detergent fiber}

ANOVA showed that the difference in NDF concentration between 2008 and 2009 was not significant (Table 2). Nitrogen treatments significantly decreased NDF concentration of forage corn as the broiler litter increased. No significant difference in NDF concentration was observed for different levels application of urea fertilizer (Fig. 6). In the regression analysis, NDF showed a decreasing trend with increasing rate of nitrogen from broiler litter, but the NDF urea treated plots, generally remained unchanged (Table 2).

Stover NDF and ADF concentrations were significantly greater for unfertilized control treatment than for soil amendment by $\mathrm{N}$ treatments (Fig. 6), suggesting that a larger portion of the nitrogen and other nutrients taken up by the crop were derived from the fertilizer and broiler litter, as has been demonstrated elsewhere (Cao et al., 2000; Mahala et al., 2007). The decreased lignin concentration is associated with greater digestibility of the cell wall (Beck et al., 2007; Miron $e t$ al., 2007).

\section{Acid detergent fiber}

In the present study the ADF of forage corn was significantly affected by nitrogen treatments. No significant difference in $\mathrm{ADF}$ concentration was observed for different levels application of urea fertilizer (Fig. 7). However, forage ADF ( $\mathrm{p} \leq 0.05)$ decreased linearly as broiler litter increased (Table 3).

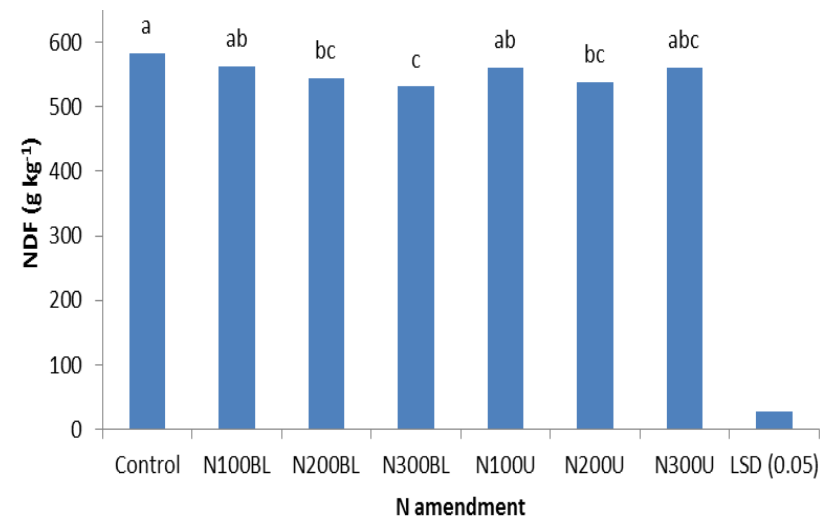

Fig. 6. The effects of $\mathrm{N}$ source and rate on NDF concentration of silage corn. Means with the different letters show significant difference (LSD, $\mathrm{P} \leq 0.05)$. See Fig. 2 for abbreviations
Higher nitrogen rates appeared to delay plant maturity for later harvests and increased plant digestibility (Coleman et al., 2004). The results of the current study are agreement with other researches that suggested the linear effect of broiler litter on digestibility and on fiber concentration. The application of $\mathrm{N}$ in broiler litter increased nutritive value and fiber digestibility (Adeli et al., 2005).

\section{Crudeprotein}

There was no difference between years for crude protein (Table 3). Compared with the unfertilized treatment, both fertilizer and broiler litter application increased the concentration and yield of crude protein (Fig. 8). The plants receiving lower values of nitrogen fertilizer had a lower crude protein concentration when compared with the other levels of nitrogen, which is similar to the results observed by Eghball and Power (1999).

Protein forage concentration showed a linear response to nitrogen levels. An increase in nitrogen in the form of broiler litter or urea fertilizer linearly improved the protein content (Table 3). The average crude protein concentration and protein yield were approximately $5 \%$ and $12 \%$ greater, respectively, for broiler litter than for commercial fertilizer application (Fig. 8 and 9). The nitrogen uptake from manure treatments increased the crude protein compared with chemical fertilizer. Broiler litter contains most of the secondary nutrients and micronutrients required for crop growth (Adeli et al., 2015) and increase protein yield compare to commercial fertilizer and has a good availability of macro- and micronutrients along with $\mathrm{N}$ and by contrast, Abbasi $e t$ al. (2010) reported similar results when comparing poultry litter and urea fertilizer.

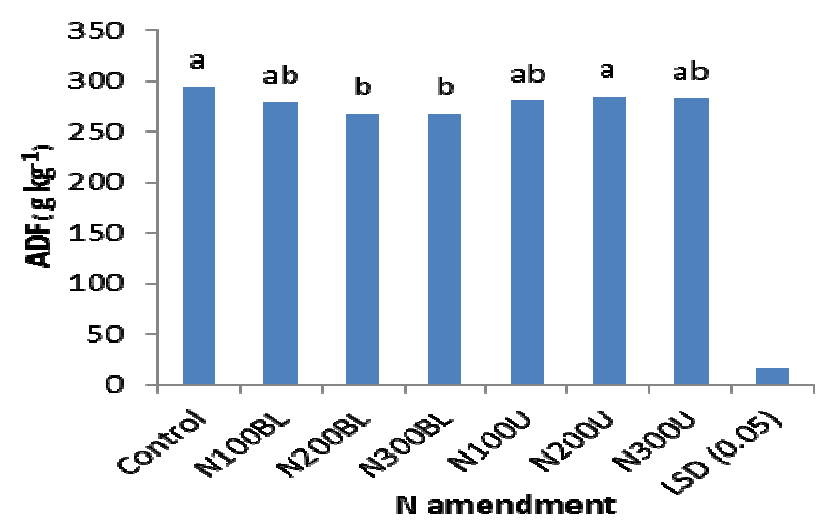

Fig. 7. The effects of $\mathrm{N}$ source and rate on ADF concentration of silage corn. Means with the different letters show significant difference (LSD, $\mathrm{P} \leq 0.05)$. See Fig. 2 for abbreviations

Table 3. The effects of $\mathrm{N}$ source and rate on ADF, protein concentration, protein yield and aboveground dry matter of silage corn

\begin{tabular}{|c|c|c|c|c|}
\hline S.O.V & $\mathrm{ADF} \dagger$ & Protein conc. & Protein yield & Aboveground dry matter \\
\hline Year & $\mathrm{NS} \neq$ & NS & NS & NS \\
\hline $\mathrm{N}$ amendment & $* *$ & ** & ** & ** \\
\hline Year $\times \mathrm{N}$ amendment & NS & NS & NS & NS \\
\hline Litter linear & ** & ** & ** & ** \\
\hline Litter quadratic & NS & NS & NS & NS \\
\hline Fertilizer linear & NS & ** & ** & ** \\
\hline Fertilizer quadratic & NS & NS & NS & NS \\
\hline
\end{tabular}




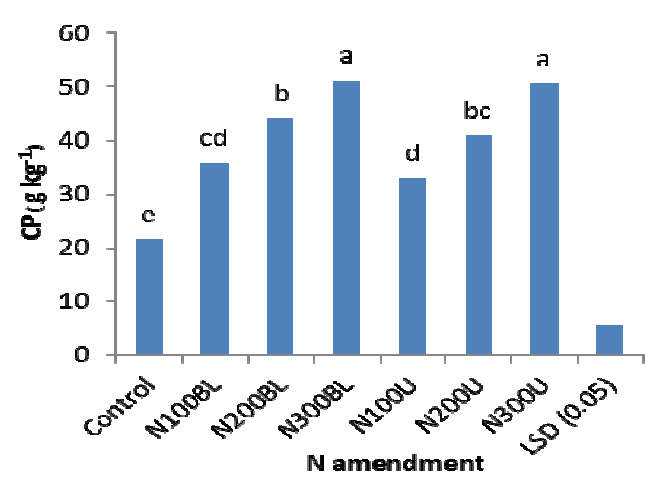

Fig. 8. The effects of $\mathrm{N}$ source and rate on crude protein (CP) concentration of silage corn. Means with the different letters show significant difference (LSD, $\mathrm{P} \leq 0.05$ ). See Fig. 2 for abbreviations

Corn crude protein concentration and yield increased significantly as broiler litter and commercial fertilizer applications increased (Table 3). The increase in crude protein concentration with increased nitrogen levels (Fig. 10) could be due to nitrogen application, which enhances amino acid formation.

Ruttunde et al. (2001) found that the nitrogen content of corn stover is an indicator of stover feed quality. The increase in nitrogen uptake of the stover with manure application means an improvement in the nutritive value of the stover, which in turn would have major implications for resource-poor farmers to whom corn is a major feed source for their animals. Montemurro et al. (2006) reported that the postanthesis $\mathrm{N}$ uptake was higher than $\mathrm{N}$ uptake during vegetative stages in maize ( 59.1 and $40.9 \%$ of the total $\mathrm{N}$ uptake, respectively). Conversely, continuous of manure $\mathrm{N}$ mineralization during the last phenological stages (Alizadeh et al., 2012) strongly affected the process of $\mathrm{N}$ uptake and translocation.

\section{Drymatter}

The dry matter was significantly affected by soil nitrogen amendment. Both soil nitrogen amendment and nitrogen source significantly affected dry matter (Table 3). Average aboveground dry matter was approximately 11.4 and $1.5 \mathrm{Mg}$ $\mathrm{ha}^{-1}$ greater for broiler litter than unfertilized treatment and commercial fertilizer application, respectively (Fig. 10).

Although nitrogen supplied either as urea fertilizer or broiler litter significantly increased forage corn yield, the increased corn forage yield in broiler treatments could be the result of better utilization of nutrients by the crop. Subedi $e t$ al. (2006) indicated that forage yield increased exponentially with nitrogen rate and highest yield was obtained with $225 \mathrm{~kg} \mathrm{~N}$ ha ${ }^{1}$. In agreement with the results of this study, the remarkable effect of broiler litter application on corn yield could be associated to its favourable effect on soil physical and biological properties (Hati et al., 2001; Sistani et al., 2008). Broiler litter application as a soil amendment for corn provided appreciable forage with high dry matter. Similar results were found by Eghball and Power (1999), who observed that compost or manure application resulted in similar maize grain yield of mineral fertilizer and by Alizadeh et al. (2012), who reported that poultry manure could be used to sustain plant production in a calcareous soil.

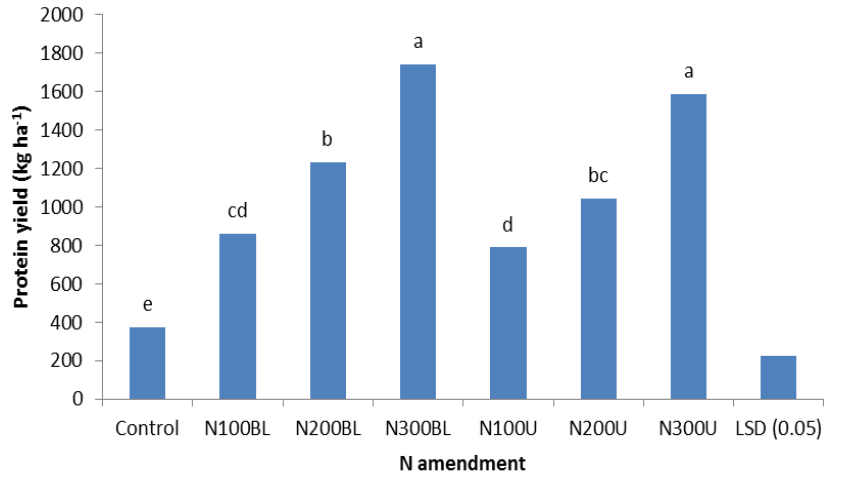

Fig. 9. The effects of $\mathrm{N}$ source and rate on protein yield concentration of silage corn. Means with the different letters show significant difference (LSD, $\mathrm{P} \leq 0.05$ ). See Fig. 2 for abbreviations

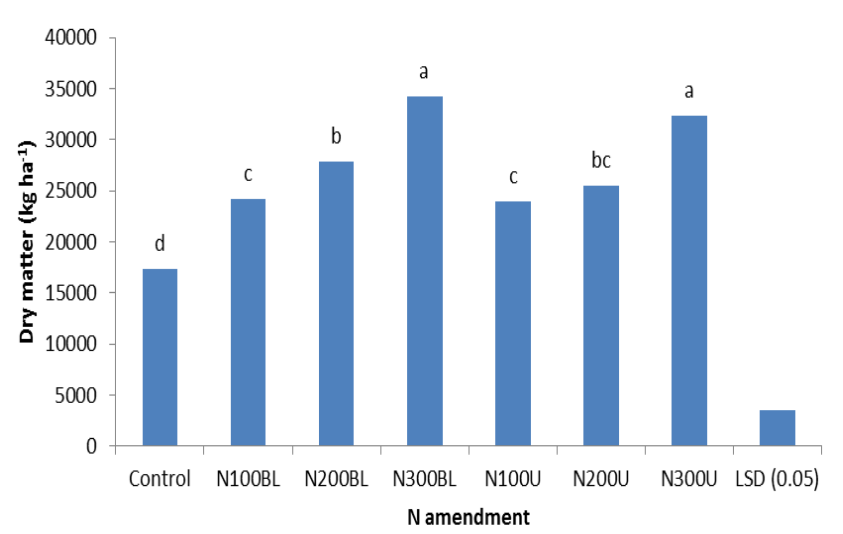

Fig. 10. The effects of $\mathrm{N}$ source and rate on dry matter concentration of silage corn. Means with the different letters show significant difference (LSD, $\mathrm{P} \leq 0.05$ ). See Fig. 2 for abbreviations

\section{Conclusions}

The results suggested that nitrogen applied to forage corn through broiler litter at the recommended rate for inorganic $N$ fertilization is almost as effective in terms of forage corn micronutrients as urea fertilizer. It can be concluded that the corn properties (micronutrients, protein, NDF, ADF) and forage yield of corn were affected by broiler litter application and the response was better at higher rates of broiler litter. Thus, broiler litter should be applied as an organic fertilizer to provide suitable corn production of suitable quality. The profitability of forage corn production might be increase by replacing chemical fertilizers with organic manure.

\section{Acknowledgements}

The authors are grateful to Shahrekord University for financial support. The authors also wish to acknowledge Dr. Ardeshir Adeli for his critical comments regarding the experimental setup, language and construction of this manuscript. 


\section{References}

Abbasi MK, Khaliq A, Shafiq M, Kazmi M, Imran A (2010). Comparatative effectiveness of urea $\mathrm{N}$, poultry manure and their combination in changing soil properties and maize productivity under rainfed conditions in northeast Pakistan. Experimental Agriculture 46:211-230.

Adeli A, Sistani KR, Rowe DE, Tewolde H (2005). Effects of broiler litter on soybean production and soil nitrogen and phosphorus concentrations. Agronomy Journal 97:314-321.

Adeli A, Sistani KR, Rowe DE, Tewolde H (2005). Effects of broiler litter on soybean production and soil nitrogen and phosphorus concentrations. Agronomy Journal 97:314-321.

Alizadeh P, Fallah S, Raiesi F (2012). Potential N mineralization and availability to irrigated maize in a calcareous soil amended with organic manures and urea under field conditions. International Journal of Plant Production 6:493-512.

Amanullah R, Khattak A, Khalil SK (2009). Plant density and nitrogen effects on maize phenology and grain yield. Journal of Plant Nutrition 32:246-260.

ANKOM Technologies (2003). Method for determining neutral detergent fiber and In vitro true digestibility with daisy ${ }^{\text {II }}$ incubator. ANKOM Technologies, Macedon, NY.

Annicchiarico G, Caternolo G, Rossi E, Martiniello P (2011). Effect of manure vs. fertilizer inputs on productivity of forage crop models. International Journal of Environmental Research and Public Health 8(6):1893-1913.

Beck PA, Hutchison S, Gunter SA, Losi TC, Stewart CB, Capps PK, Phillips JM (2007). Chemical composition and in situs dry matter and fiber disappearance of sorghum $\times$ Sudangrass hybrids. Journal of Animal Science 85:545-555.

Bremner JM, Breintenbeck GA (1983). A simple method for determination of ammonium in semimicro Kjeldahl analysis of soils and plant materials using a block digester. Communication in Soil Science and Plant Analysis 14:905-913.

Cao YF, Li, Y, Liu, RC, Liu, GY, Li, JG, Pi, RY, Fenng LM (2000). Effect of chemical complex treatment on growth performance of beef cattle. China Herbivores 2(1):13-16.

Carter MR, Gregorich EG (2008). Soil Sampling and Methods of Analysis, $2^{\text {nd }}$ Ed. CRC Press, Taylor \& Francis, Boca Raton, FL.

Coleman SW, Moore JE, Wilson JR (2004). Quality and Utilization. In Moser LE et al. (Eds). Warm-season $\left(\mathrm{C}_{4}\right)$ grasses. Agron Mongr 45. ASA, CSSA and SSSA, Madison, WI.pp 267-308.

Demir K, Sahin O, Kadioglu YK, Pilbeam DJ, Gunes A (2010). Essential and non-essential element composition of tomato plants fertilized with poultry manure. Scientia Horticulturae 127:16-22.

Eghball B, Power JF (1999). Composted and noncomposted manure application to conventional and no-tillage systems: corn yield and nitrogen uptake. Agronomy Journal 91:819-825.

Fallah S, Ghalavand A, Raesis F (2013). Soil chemical properties and growth and nutrient uptake of maize grown with different combination of broiler litter and chemical fertilizer in a calcareous soil. Communication in Soil Science and Plant Analysis 44:31203136.
Fallah S, Tadayyon A (2010). Uptake and nitrogen efficiency in forage maize: Effect of nitrogen and plant density. Agrociencia 44:549560.

Hao H, Wei Y, Yang X, Feng Y, Wu C (2007). Effects of different nitrogen fertilizer levels on $\mathrm{Fe}, \mathrm{Mn}, \mathrm{Cu}$ and $\mathrm{Zn}$ concentrations in shoot and grain quality in rice (Oryza sativa). Rice Science 14:289294.

Hart J, Sullivan D, Gamroth M, Downing T, Peters A (2009). Corn silage (western Oregon). Nutrient Management Guide pp:1-13.

Hati KM, Mandal KG, Misra AK, Ghosh PK, Acharya CL (2001). Effect of irrigation regimes and nutrient management on soil water dynamics, evapo-transpiration and yield of wheat (Triticum aestivum) in vertisol. Indian Journal of Agricultural Sciences 71:581587.

Heckman JR, Sims JT, Beegle DB, Coale FJ, Herbert SJ, Bruulsema TW, Bamka WJ (2003). Nutrient removal by corn grain harvest. Agronomy Journal 95:587-591.

Jackson ML (1962). Soil Chemical Analysis. Englewood Cliffs, NJ, USA: Prentice-Hall, Inc.

Kacar B (1972). Bitki Analizleri. Ankara, A Ziraat Fak Yay No 155, 453.

Khaliq A, Kaleem Abbasi A (2015). Improvements in the physical and chemical characteristics of degraded soils supplemented with organic-inorganic amendments in the Himalayan region of Kashmir, Pakistan. CATENA 126:209-219.

Li H, Liang Li, Wegenast T, Longin CF, Xu X, Melchinger AE, Chen S (2010). Effect of $N$ supply on stalk quality in maize hybrids. Field Crops Research 118:208-214.

Ma BL, Dwyer LM, Gregorich EG (1999). Soil nitrogen amendment effects on seasonal nitrogen mineralization and nitrogen cycling in maize production. Agronomy Journal 91:1003-1009.

Mahala AG, Babiker SA, Gutbi N E (2007). Improvement of digestibility of sugar cane baggase by fermentation with chicken manure. Research Journal of Agriculture and Biological Sciences 3(2):115-118.

Martin RC, Astatkie T, Cooper JM (1998). The effect of soybean variety on corn-soybean intercrop biomass and protein yields. Canadian Journal of Plant Science 78:289-294.

Mertens DR (1991). Neutral detergent fiber. In: Proceedings of the National Forage Testing Association Forage Analysis Workshop. Milwaukee, WI pp A12-A16.

Mikkelsen RL (2000). Nutrient management for organic farming: A case study. Journal of Natural Resources and Life Sciences Education 29: 88-92.

Miron J, Zuckerman E, Adin G, Soloman R, Shoshani E, Nikbachat M, Yosef E, Zenou A, Gershon Weinberg Z, Chen Y, Halachmi I, Ben-Ghedalia D (2007). Comparison of two forage sorghum varieties with corn and the effect of feeding their silages on eating behavior and lactation performance of dairy cows. Animal Feed Science and Technology 139:23-39.

Mohanty S, Paikaray NK, Raja Rajan A (2007). Availability and uptake of phosphorus from organic manures in groundnut (Arachis bypogea L.) - corn (Zea mays L.) sequence using radio tracer technique. Geoderma 133:225-230. 
Montemurro F, Maiorana M, Ferri D, Convertini G (2006). Nitrogen indicators, uptake and utilization efficiency in a maize and barley rotation cropped at different levels and sources of $\mathrm{N}$ fertilization. Field Crops Research 99:114-124.

Nyiraneza JS, Snapp S (2007). Integrated management of inorganic and organic nitrogen and efficiency in potato systems. Soil Science Society of America Journal 71:1508-1515.

Page AL, Miller RH, Keeney DR (1982). Methods of Soil Analysis. Part 2, Chemical and Microbiological Properties ( $\left.2^{\mathrm{ed}}\right)$. Am Soc of Agron Madison, Wisconsin.

Ruttunde HFW, Zerbini E, Chandra S, Flower DJ (2001). Stover quality of dual-purpose sorghums: genetic and environmental sources of variation. Field Crops Research 71:1-8.

Sagarpa (2003). Programa Especial Concurrente para el Desarrollo Rural Sustentable 2002-2006.

SAS Institute (2003). The SAS System for Windows, Release 9.1.3. SAS Institute, Cary, NC.

Schomberg HH, Endale DM, Jenkins MB, Sharpe RR, Fisher DS, Cabrera ML, McCracken DV (2009). Soil test nutrient changes induced by poultry litter under conventional tillage and no-tillage. Soil Science Society of America Journal 73:154-163.

Shakhawat HM, Akbar Hossain, Sarkar MAR, Jahiruddin M, Teixeira da Silva JA, Israil Hossai M (2016). Productivity and soil fertility of the rice-wheat system in the High Ganges River Floodplain of Bangladesh is influenced by the inclusion of legumes and manure. Agriculture, Ecosystems \& Environment 218: 40-52.

Sistani KR, Adeli A, McGowen SL, Tewolde H, Brink GE (2008). Laboratory and field evaluation of broiler litter nitrogen mineralization. Bioresource Technology 99:2603-2611.
Stone PJ, Sorensen IB, Reid JB (1998). Effect of plant population and nitrogen fertilizer on yield and quality of super sweet corn. Proc Ann Conf Agron Soc New Zealand 28:1-5.

Subedi KD, Ma BL, Smith DL (2006). Response of a leafy and nonleafy maize hybrid to population densities and fertilizer nitrogen levels. Crop Sciences 46:1860-1869.

Van Soest PJ, Robertson JB, Lewis BA (1991). Methods for dietary fiber, neutral detergent fiber, and nonstarch polysaccharides in relation to animal nutrition. Journal of Dairy Science 74:35833597.

Weiss WP (1994). Estimation of digestibility of forages by laboratory methods. In: Fahey Jr GC (Ed). Forage Quality, Evaluation, and Utilization. American Society Agronomy, Madison, WI, pp 644 681.

Yaduvanshi NPS, Sharma DR (2008). Tillage and residual organic manures/chemical amendment effects on soil organic matter and yield of wheat under sodic water irrigation. Soil and Tillage Research 98:11-16.

Zhang Sh, Li Zh, Liu J, Li Q, Yang X (2015). Long-term effects of straw and manure on crop micronutrient nutrition under a wheat-maize cropping system. Journal of Plant Nutrition 38:742-753.

Zingore S, Delve RJ, Nyamangara J, Giller KE (2008). Multiple benefits of manure: The key to maintenance of soil fertility and restoration of depleted sandy soils on African smallholder farms. Nutrient Cycling in Agroecosystems 80:267-282. 